\title{
MENINGKATKAN AKTIVITAS DAN HASIL BELAJAR MATA KULIAH PENGETAHUAN LINGKUNGAN HIDUP MELALUI PENDEKATAN SCIENTIFIC MAHASISWA
}

\author{
Muh. Rapi \\ Dosen Jurusan Pendidikan Biologi Fakultas Tarbiyah dan Keguruan, \\ UIN Alauddin Makassar, Kampus II J1. H. M. Yasin Limpo No 36 Samata-Gowa, \\ Sulawesi Selatan 92118, Telepon: (0411) 424835, E-mail: mrapi@uin-alauddin.ac.id
}

\begin{abstract}
Abstrak
Penelitian ini bertujuan untuk mengetahui peningkatan aktivitas belajar dan hasil belajar dengan menerapkan pendekatan scientific pada mata kuliah pengetahuan lingkungan hidup mahasiswa Prodi Pendidikan Biologi angkatan 2013. Jenis penelitian ini adalah penelitian tindakan kelas (Classroom Action Research) mengikuti model desain Sanford dan Kemmis berbentuk siklus yang terdiri dari empat tahapan, yaitu: 1) perencanaan (planning), 2) pelaksanaan (acting), 3) pengamatan (observing), dan 4) refleksi (reflecting). Data yang dikumpulkan di analisis secara deskriptif kualitatif dan deskriptif kuantitatif. Hasil penelitian ditemukan penerapan pendekatan scientific dalam pembelajaran mata kuliah pengetahuan lingkungan hidup dapat meningkatkan aktivitas belajar mahasiswa. Skor perolehan aktivitas belajar mahasiswa pada aspek yang diamati dalam pembelajaran siklus I dengan persentase rerata $72,36 \%$ dan pada siklus II meningkat menjadi rerata $84,76 \%$. Hal ini berarti terjadi peningkatan sebesar $12,40 \%$. Begitu pula dengan hasil belajar mahasiswa dengan penerapan pendekatan scientific cenderung semakin meningkat dari siklus I ke siklus II. Hal ini dapat di lihat dari skor rerata yang diperoleh mahasiswa meningkat yaitu rerata 77,56 pada siklus I menjadi rerata 83,78 pada siklus II. Dengan demikian terjadi peningkatan skor hasil belajar dari siklus pertama ke siklus kedua sebesar 6,22.
\end{abstract}

Kata Kunci: Aktivitas belajar, hasil belajar, pendekatan scientific

\begin{abstract}
Abstrack
This study aims to determine the increased activity of learning and learning outcomes by applying a scientific approach to the subject of environmental science students of Biology Education Studies Program class of 2013. The research is a classroom action research design model Sanford and Kemmis shaped cycle consists of four phases , namely: 1) planning, 2) acting, 3) observing, and 4) reflecting. Data were analyzed descriptively qualitative and quantitative descriptive. The research found the application of a scientific approach to learning courses environmental knowledge can improve students' learning activities. Scores acquisition of learning activities of students on the learning aspects observed in the first cycle with the average percentage of $72.36 \%$ and the second cycle increased to an average $84.76 \%$. This means an increase of $12.40 \%$. Similarly, the student results with the application of scientific approach tends to increase from the first cycle to the second cycle. It can be seen
\end{abstract}


from the average score obtained by increasing that average 77.56 students in the first cycle to average 83.78 in the second cycle. Thus an increase in the score results learned from the first cycle to the second cycle of 6.22 .

Keywords: learning activities, learning outcomes, scientific approach

\section{PENDAHULUAN}

Pengembangan bidang pendidikan terus dilakukan untuk meningkatkan kualitas dan mencapai tujuan pendidikan nasional. Pendidikan nasional menurut UndangUndang Nomor 20 Tahun 2003 bertujuan mengembangkan potensi peserta didik, agar menjadi manusia yang beriman dan bertakwa kepada Tuhan Yang Maha Esa, berakhlak mulia, sehat, berilmu, cakap, kreatif, mandiri, dan menjadi warga negara yang demokratis, serta bertanggung jawab.

Salah satu bentuk pembaharuan pendidikan tersebut di atas adalah perubahan kurikulum dari kurikulum 2006 yang dikenal Kurikulum Tingkat Satuan Pendidikan (KTSP) ke kurikulum 2013. Perubahan kurikulum perlu diikuti dengan perubahan cara pandang terutama oleh pendidik (dosen) dalam mengimplementasikan kurikulum tersebut. Salah satunya adalah dengan menerapkan berbagai pendekatan dan strategi dalam membelajarkan peserta didik (mahasiswa) untuk mencapai kompetensi yang telah ditentukan.

Pelaksanaan kegiatan pembelajaran, pendidik di samping harus menguasai materi, tentu harus memahami cara materi ajar itu dibelajarkan. Kegagalan pendidik dalam menyajikan materi ajar bukan disebabkan kerena dosen tidak menguasai bahan ajar, tetapi bisa disebabkan oleh faktor metode yang digunakan oleh pendidik dalam menyampaikan materi pelajaran tersebut. Akibatnya, mahasiswa tidak belajar dengan suasana belajar yang aktif, efektif dan menyenangkan.

Membelajarkan mahasiswa di kelas merupakan salah satu tugas utama dari dosen sebagai bentuk pelaksanaan tri dharma perguruan tinggi. Namun demikian, tidaklah berarti bahwa dosen yang akan mendominasi pelaksanaan kegiatan tersebut. Menurut UU No. 20 tahun 2003, pasal 1 ayat 20 ditegaskan bahwa pembelajaran didefinisikan sebagai "proses interaksi antar peserta didik, antara peserta didik dengan pendidik dan sumber belajar pada suatu lingkungan belajar."

Fakta yang sering dilihat di lapangan yaitu, masih sering dijumpai mahasiswa tidak terlibat aktif dan bersikap pasif dalam kegiatan pembelajaran. Ketidakaktifan dalam proses pembelajaran ini akan nampak misalnya, mahasiswa; malas mengikuti pelajaran, tidak memperhatikan pada saat dosen menerangkan, mengantuk, melamun, berbicara dengan temannya, tidak mau bertanya dan tidak ada respon pada saat diberi pertanyaan, dan sebagainya. Kondisi seperti yang disebutkan tentu akan mempengaruhi kelancaran proses pembelajaran, sehingga suasana belajar kurang hidup serta membosankan, dan tidak mustahil akan berpengaruh terhadap hasil belajar.

Keaktifan atau kegiatan dalam pembelajaran berarti bahwa pelajar sengaja dan 
sadar menetapkan tujuan pembelajaran yang bermakna dan kemudian terus-menerus dan secara aktif mengkaji dan melakukan tugas-tugas belajar dalam rangka mencapai tujuan-tujuan pembelajaran. Pentingnya aktivitas siswa dalam belajar diungkapkan oleh banyak ahli dari berbagai disiplin ilmu, seperti John Dewey dalam teorinya tentang pendidikan berbasis inquiry (Dewey 1938), Jean Piaget yang penekanannya pada gagasan konstruktivis dalam belajar (Piaget 1950), Lev Vygotsky dalam tulisannya tentang makna konstruksi sosial dalam belajar (Vygotsky 1978).

Aktivitas pembelajaran merupakan praktik-praktik yang memperlakukan peserta didik tidak hanya sebagai subjek yang diberi perlakukan oleh pendidik tetapi juga berperan sebagai agen tindakan kognitif yang didistribusikan antara pendidik dan peserta didik (Yaumi dan Ibrahim, 2013a:37). Aktivitas belajar siswa terbagi menjadi beberapa bagian (Dave, 2005:35; Djamarah, 2008: 38-45; Dierich dalam Hanafia dan Suhana, 2010: 24), yakni: (a) Aktivitas visual (visual activities) seperti membaca, menulis, melakukan eksperimen, dan demonstrasi; (b) Aktivitas lisan (oral activities) seperti bercerita, membaca, tanya jawab, diskusi, dan menyanyi; (c) Aktivitas mendengarkan (listening activities) seperti mendengarkan penjelasan guru, ceramah, dan pengarahan; (d) Aktivitas gerak (motor activities) seperti senam, atletik, menari, dan melukis; (e) Aktivitas menulis (writing activities) seperti mengarang, membuat makalah, dan membuat surat; (f) aktivitas metrik yaitu melakukan percobaan, memilih alat, melaksanakan pameran, membuat model dan menyelenggarakan permainan; $(\mathrm{g})$ aktivitas mental yaitu merenungkan, mengingat, memecahkan masalah, menganalisis faktor-faktor, melihat hubungan-hubungan, dan membuat keputusan; dan (h) aktivitas emosional yaitu minat, membedakan, berani, tenang dan lain-lainnya.

Yatmoko (2011) mengajukan beberapa indikator aktivitas belajar adalah; (1) antusiasme peserta didik dalam pembelajaran, (2) interaksi peserta didik dengan pendidik, (3) interaksi antar teman sebaya, (4) kerjasama kelompok, (5) aktivitas peserta didik dalam diskusi kelompok, (6) usaha peserta didik dalam mengikuti pembelajaran, dan (7) partisipasi peserta didik dalam menyimpulkan materi pembelajaran.

Mahasiswa pendidikan biologi adalah calon guru biologi memiliki peranan yang strategis dalam memperbaiki proses pembelajaran biologi di sekolah di masa yang akan datang. Salah satu kelemahan proses pembelajaran biologi di sekolah adalah: sintak pembelajaran belum didasari oleh nilai dan semangat scientific method. Oleh karena itu, selama proses penyiapan menjadi guru, kepada para mahasiswa harus dilakukan upaya internalisasi nilai dan semangat scientific method.

Hasil penelitian Nurrohman (2008: 20) menyarankan kepada dosen agar mengembangkan proses pembelajarannya berdasarkan pendekatan scientific, karena pendekatan ini secara teoritis dapat digunakan untuk internalisasi scientifik method kepada para mahasiswa calon guru. Praktik ini akan berdampak jangka panjang, karena mahasiswa yang saat ini sudah terinternalisasi scientific method, kelak pada saat mengajar di kelas diharapkan mampu mengajarkan materi pelajaran secara lebih 
bermakna kepada para siswanya.

Metode scientific pertama kali diperkenalkan ke ilmu pendidikan Amerika akhir abad ke-19, dengan penekanan pada metode yang mengarah pada fakta-fakta ilmiah. Metode scientific ini memiliki karakteristik "doing science". Metode ini memudahkan guru atau pengembang kurikulum untuk memperbaiki proses pembelajaran, yaitu dengan memecah proses ke dalam langkah-langkah atau tahapan-tahapan secara terperinci yang memuat instruksi untuk siswa melaksanakan kegiatan pembelajaran (Atsnan dan Gazali, 2013:7). Pendekatan scientific atau lebih umum dikatakan pendekatan ilmiah merupakan pendekatan dalam kurikulum 2013.

Menurut Nurohman (2008:7), pendekatan Scientific memiliki makna yang sama dengan Scientific Method adalah jalan untuk membuat dan menjawab pertanyaan ilmiah (scientific questions) melalui observasi dan atau eksperimen. Adapun tahap-tahap Scientific Method dapat disebutkan terdiri dari: (1) Membuat pertanyaan ilmiah, (2) Melakukan kajian teoritis (research), (3) Mengkonstruksi hipotesis, (4) Menjalankan observasi dan atau eksperimen, (5) Menganalisis data dan membuat kesimpulan, (6) Melaporkan hasil (publikasi). Permendiknas Nomor 81A tahun 2013 pada lampiran empat tentang pedoman umum pembelajaran ditegaskan bahwa, pendekatan scientific dalam proses pembelajaran terdiri atas lima pengalaman belajar pokok yaitu; (a) mengamati, (b) menanya, (c) mengumpulkan informasi, (d) mengasosiasi, dan (e) mengkomunikasikan.

Berdasarkan pengamatan peneliti pada mahasiswa Fakultas Tarbiyah dan Keguruan, Prodi Pendidikan Biologi, semester II angkatan 2013/2014 yang mengikuti mata kuliah pengetahuan lingkungan hidup, masih ditemukan peserta didik yang tidak aktif bertanya, tidak aktif menjawab atau menanggapi pertanyaan yang diberikan, terlihat mengantuk dan tidak memperhatikan penjelasan, ditambah lagi jadwal mata kuliah ini dibelajarkan pada siang hari, yaitu dari pukul 13.50 sampai 15.30 Wita.

Mencermati permasalahan tersebut di atas, maka dibutuhkan upaya pemecahan masalah yaitu dengan menerapkan pendekatan scientific (mengamati, menanya, mencoba menalar, dan menyaji) sehingga peserta didik dalam proses pembelajaran berlangsung aktif dan diharapkan dengan keaktifan tersebut, hasil belajar akan meningkat khususnya dalam mata kuliah pengetahuan lingkungan hidup yang merupakan salah satu mata kuliah yang diberikan kepada mahasiswa prodi Pendidikan Biologi Fakultas Tarbiyah dan Keguruan.

Hasil belajar merupakan bentuk tingkah laku yang dimiliki peserta didik setelah menyelesaikan pengalaman belajar (Sudjana, 2005: 111). Hasil belajar merupakan ukuran atas suatu kegiatan dalam proses pembelajaran. Indikator keberhasilan belajar menurut Fathurrohman dan Sutikno (2011:113) belajar dikatakan berhasil apabila; (1) daya serap terhadap bahan pengajaran yang diajarkan mencapai prestasi tinggi secara individu dan kelompok, (2) perilaku yang digariskan dalam tujuan pembelajaran telah dicapai oleh peserta didik baik secara individu dan kelompok, dan (3) terjadinya proses 
pemahaman materi yang secara sekuensial mengantarkan materi pada tahap berikutnya. Menurut Suparman (2012:151) taksonomi kognisi berkenaan dengan ingatan atau pengandalan terhadap pengetahuan. Taksonomi afektif berkenaan dengan minat, sikap dan nilai, penghargaan dan penyesuaian diri, dan taksonomi psikomotor berkanaan dengan fungsi otot dan keterampilan gerak yang membutuhkan koordinasi otot.

Adapun deskripsi mata kuliah pengetahuan lingkungan hidup membahas tentang pengertian lingkungan hidup, ekologi sebagai dasar pengetahuan lingkungan, hubungan antara makhluk hidup dalam ekosistem, permasalahan lingkungan hidup global, regional, nasional dan lokal, penduduk dan permasalahannya terhadap lingkungan hidup, dampak kegiatan manusia terhadap lingkungan: fisik, kimia, biologi, dan sosial, sumber daya alam (SDA) dan lingkungan hidup serta pengelolaannya, kesehatan dan lingkungan, pencemaran lingkungan, peraturan perundang-undangan tentang lingkungan hidup serta Islam dan etika lingkungan.

Berdasarkan teori dan masalah tersebut di atas, maka kerangka berfikir yang digunakan dalam penelitian ini adalah sebagai berikut:

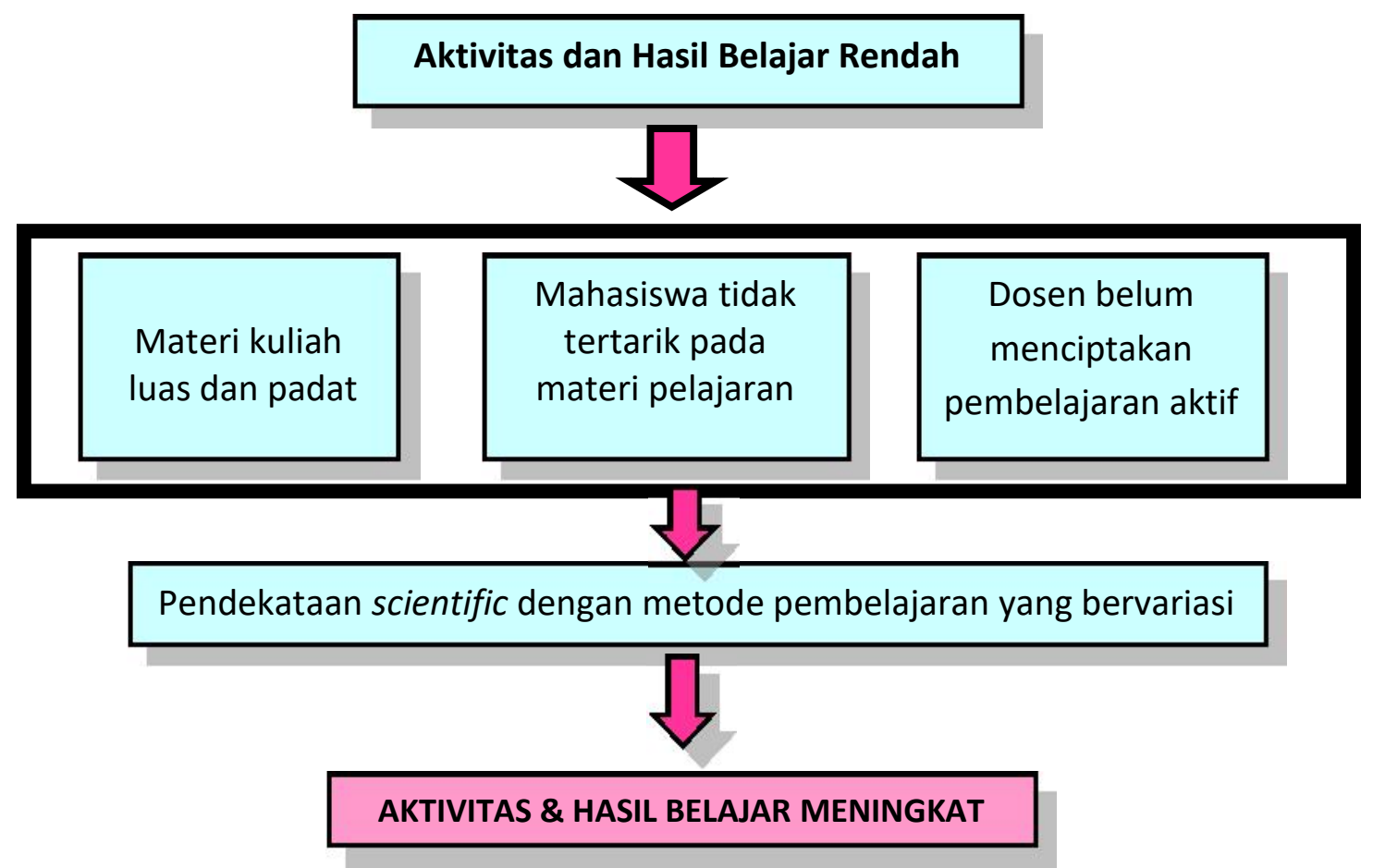

Gambar 1. Kerangka Berpikir Penelitian

\section{METODOLOGI PENELITIAN}

Jenis penelitian ini adalah penelitian tindakan kelas (Classroom Action Research) yang menurut Grundy dan Kemmis (Sanjaya, 2009:30) bahwa jenis penelitian ini bertujuan untuk peningkatan proses dan kualitas pembelajaran, pengembangan profesional dan peningkatan situasi tempat pembelajaran berlangsung. Tujuan itu dapat dicapai dengan melakukan refleksi untuk mendiagnosis keadaan kemudian 
mengujicobakan secara sistematis berbagai tindakan alternatif dalam memecahkan permasalahan pembelajaran di kelas (Rusman dan Rahman, 2010: 49).

Penelitian ini dilaksanakan pada semester genap tahun akademik 2013/2014, yaitu dari bulan April sampai Juni 2014. Subjek penelitian ini adalah mahasiswa semester II Prodi Pendidikan Biologi, yang mengikuti mata kuliah Pendidikan Lingkungan Hidup, dengan jumlah 41 orang mahasiswa, terdiri dari 9 orang laki-laki dan 32 perempuan. Jumlah laki-laki dan perempuan tidak seimbang karena sejalan hasil penelitian Romanov dan Nevgi (2008: 153) bahwa tidak ada perbedaan yang signifikan secara statistik antara laki-laki dan perempuan dalam hal memanfaatkan berbagai komponen materi pembelajaran.

Metode pengumpulan data yang digunakan dalam penelitian yaitu observasi untuk mengamati keaktifan mahasiswa dalam proses pembelajaran, dokumentasi berupa fotofoto sebagai gambaran pelaksanaan penelitian dengan pendekatan scientific, dan tes pengetahuan yang digunakan untuk menilai hasil belajar mahasiswa setelah mengikuti pembelajaran.

Prosedur penelitian ini mengikuti model desain Sanford dan Kemmis (Taniredja, 2010: 28) dengan kegiatan-kegiatan yang berbentuk siklus dengan empat tahapan, yaitu: 1) perencanaan (planning), 2) pelaksanaan (acting), 3) pengamatan (observing), dan 4) refleksi (reflecting). Di dalam alur kegiatannya, tahap pelaksanaan dan pengamatan dilakukan dalam waktu yang sama.

Penelitian tindakan kelas dirancang minimal dalam dua siklus dan jika indikator keberhasilan belum tercapai maka dilanjutkan pada siklus berikutnya dengan skema tindakan digambarkan sebagai berikut ini:



Gambar 2: Model PTK Gabungan Sanford dan Kemmis 
Teknik analisis data yang digunakan dalam penelitian ini berupa narasi deskriptif kualitatif dan deskriptif kuantitatif. Deskriptif kualitatif, yaitu metode pengolahan data yang digunakan terhadap data berupa uraian yang diperoleh melalui observasi. Deskriptif kuantitatif, yaitu metode pengolahan data dengan menggunakan rumusrumus statistik. Metode kuantitatif ini digunakan untuk mengolah data yang berupa angka-angka.

Keberhasilan pada penelitian ini adalah apabila mahasiswa mampu mengikuti pembelajaran Mata Kuliah Pengetahuan Lingkungan secara aktif, yaitu aktif mengamati, bertanya, menalar, mencoba dan menyajikan materi yang dibelajarkan pada perkuliahan. Pedoman penilaian hasil belajar setiap mata kuliah untuk program diploma dan sarjana (Pedoman Edukasi, 2013:34) yang berlaku di UIN Alauddin Makassar dinyatakan dengan huruf A, B, C, D dan E atau masing-masing bernilai 4, 3, 2, 1 dan 0. Penilaian dan konversi nilai tersebut digambarkan sebagai berikut:

Tabel 1. Penilaian dan Konversi Nilai UIN Alauddin Makassar

\begin{tabular}{cccl}
\hline Skor & Angka & Huruf & Keterangan \\
\hline $90-100$ & 4 & A & Amat Baik \\
$80-89$ & 3 & B & Baik \\
$66-79$ & 2 & C & Cukup \\
$45-65$ & 1 & D & Kurang \\
$0-45$ & 0 & E & Tidak lulus \\
\hline
\end{tabular}

Berdasarkan pedoman tersebut di atas, maka hasil belajar yang ditandai perubahan dari aspek pengetahuan dengan indikator nilai rerata perolehan minimal 80 (nilai Baik pada rentang 80-89), sedangkan aspek aktivitas belajar rerata minimal aktif $80 \%$ secara klasikal.

\section{HASIL PENELITIAN DAN PEMBAHASAN Gambaran Pra Siklus}

Penelitian ini dilakukan pada mahasiswa Prodi Pendidikan Biologi angkatan 2013. Pemilihan kelas ini berdasarkan pengamatan peneliti yang menyimpulkan bahwa terdapat beberapa masalah dalam kegiatan pembelajaran. Dalam kegiatan proses pembelajaran terdapat beberapa mahasiswa di kelas ini tergolong kurang aktif dalam mengikuti setiap langkah kegiatan pembelajaran. Hal tersebut diamati oleh peneliti pada awal perkuliahan saat kegiatan proses pembelajaran berlangsung.

Kegiatan pembelajaran belum mendorong peningkatan aktivitas dalam perkuliahan. Berdasarkan pengamatan peneliti pada mata kuliah pengetahuan lingkungan nampak bahwa mahasiswa belum berpartisipasi secara aktif dalam kegiatan pembelajaran. Keaktivan mahasiswa dalam kegiatan pembelajaran hanya sekitar $60 \%$. Dalam proses pembelajaran sebahagian mahasiswa belum berani mengemukakan pendapat bila diberi pertanyaan lisan dalam kegiatan pembelajaran, mahasiswa tidak berusaha menjawab dan mereka kesulitan mencari dan menemukan jawabannya. Dalam diskusi, sebagian mahasiswa belum menunjukan aktivitas belajar yang maksimal, 
interaksi mahasiswa belum nampak, demikian pula dengan interaksi antar kelompok. Selain itu nampak pula beberapa mahasiswa kelihatan kurang bersemangat dan kurang perhatian dalam menerima materi perkuliahan.

Hasil refleksi awal (pra siklus) peneliti mengidentifikasi beberapa faktor dan penyebab masalah yang dirangkum pada tabel 2 berikut:

Tabel 2. Asumsi Penyebab Masalah

\begin{tabular}{lll}
\hline No & Faktor & Penyebab Masalah \\
\hline 1 & Mahasiswa & $\begin{array}{l}\text { Keaktifan dalam proses pembelajaran rendah, penjelasan dosen, } \\
\text { teman sebaya kurang diperhatikan, tidak berani mengemukakan } \\
\text { pendapatnya secara lisan dan kurang berani bertanya. } \\
\text { Dosen masih mendominasi dalam kegitan pembelajaran, kurang } \\
\text { mendorong mahasiswa untuk aktif dalam kegiatan pembelajaran, } \\
\text { pemberian tugas belum maksimal. }\end{array}$ \\
2 & Dosen & $\begin{array}{l}\text { Keaktifan mahasiswa dalam kegiatan pembelajaran masih kurang, } \\
\text { strategi pembelajaran yang digunakan belum bervariasi dan lebih } \\
\text { dominan menggunakan metode ceramah. } \\
\text { Luas dan kompleks }\end{array}$ \\
& Kegiatan & Pembelajaran \\
4 & Materi &
\end{tabular}

Rendahnya keaktifan mahasiswa dalam proses pembelajaran dapat berdampak pada rendahnya hasil belajar yang dicapai. Untuk itu peneliti berupaya untuk memecahkan sebagian masalah mahasiswa melalui Penelitian Tindakan Kelas dengan penerapan pendekatan scientific dalam upaya meningkatkan aktivitas dan hasil belajar mahasiswa.

\section{Siklus I}

Tahap perencanaan siklus pertama, peneliti menetapkan tiga kali pertemuan tatap muka. Topik-topik yang dibahas pada setiap pertemuan tersebut sebagai berikut: (1) Permasalahan lingkungan global, nasional dan lokal, (2) penduduk dan permasalahannya terhadap lingkungan dan, (3) dampak kegiatan manusia terhadap lingkungan yang meliputi lingkungan fisik, kimia, biologi, dan sosial.

Secara umum langkah-langkah pembelajaran pada topik-topik tersebut di atas disusun dalam rencana pelaksanaan pembelajaran (RPP) sesuai dengan langkah-langkah pendekatan scientific. Secara garis besar kegiatan perencanaan pembelajaran yang dilakukan peneliti antara lain:

a. Membuat skenario pembelajaran sesuai dengan topik-topik materi pembelajaran untuk mencapai kompetensi dasar yang telah ditentukan dalam mata kuliah pengetahuan lingkungan.

b. Membuat instrumen yang digunakan untuk menilai aktivitas berupa lembar pengamatan dan hasil belajar berupa tes pengetahuan.

c. Menyiapkan alat dan bahan yang dibutuhkan dalam pembelajaran dengan pendekatan scientific seperti gunting, lem kertas, kertas plano, HVS dan post-it yang digunakan pada saat kunjung karya atau karya kunjung.

d. Menyiapkan gambar sesuai dengan konten materi untuk memudahkan mahasiswa mengamati permasalahan lingkungan hidup. 
e. Membuat lembar kerja (LK) sebagai panduan, pertemuan pertama mengidentifikasi masalah, penyebab, dampak terhadap manusia dan lingkungan, serta alternatif pemecahan masalah yang berhubungan dengan penduduk, makanan, air, energi, perubahan iklim, keanekaragaman hayati (diversity), pencemaran dan polusi. Pertemuan kedua penduduk dan permasalahannya terhadap lingkungan seperti masalah, dampak dan alternatif pemecahan, dan pertemuan ketiga mengidentifikasi dampak kegiatan manusia terhadap lingkungan meliputi jenis kegiatan/usaha atau sumber polutan, jenis dampak/ polutan yang ditimbulkan dan alternatif pemecahan masalah.

f. Menyiapkan gambar/video sesuai dengan konten materi untuk memudahkan mahasiswa mengamati permasalahan lingkungan hidup.

g. Mengelompokkan mahasiswa menjadi kelompok-kelompok kecil yang beranggotakan antara 5-7 orang mahasiswa untuk mendiskusikan subtopik materi yang menjadi tugas kelompok.

Pada tahap pelaksanaan tindakan ini merupakan pelaksanaan dari RPP yang sudah didesain mengikuti pendekatan scientific. Berikut ini salah satu contoh pelaksanaan pembelajaran di kelas.

Tabel 3. Pelaksanaan RPP Siklus 1

\begin{tabular}{|c|c|c|c|}
\hline No. & Kegiatan & Deskripsi & $\begin{array}{l}\text { Alokasi } \\
\text { Waktu }\end{array}$ \\
\hline \multirow[t]{2}{*}{1} & Pendahuluan & $\begin{array}{l}\text { 1. Memberi salam, selanjutnya menanyakan kabar } \\
\text { mahasiswa. } \\
\text { 2. Memberi motivasi dan apersepsi } \\
\text { - Menggunakan Model pembelajaran CTL: } \\
\text { Bagaimana menurut kalian tentang lingkungan } \\
\text { yang kalian tempati sekarang? } \\
\text { - Apakah terdapat perbedaan dari 6-7 tahun yang } \\
\text { lalu atau masih tetap sama (suhu semakin } \\
\text { meningkat, sampah semakin menumpuk, banjir, } \\
\text { kekeringan)? } \\
\text { - Jika ada perbedaan apakah perbedaannya menuju } \\
\text { ke arah yang positif atau negatif? } \\
\text { - Siapakah yang akan bertanggung jawab atas } \\
\text { perubahan lingkungan hidup tersebut? } \\
\text { 3. Menyampaikan tujuan pembelajaran dalam rangka } \\
\text { mencapai indikator kompetensi. } \\
\text { 4. Membimbing mahasiswa dalam pembentukan } \\
\text { kelompok. }\end{array}$ & 10 \\
\hline & Inti & $\begin{array}{l}\text { Mengamati } \\
\text { - Mengamati secara singkat penjelasan materi } \\
\text { melalui slide power point. } \\
\text { - Mengamati ciri-ciri dampak kegiatan manusia } \\
\text { terhadap lingkungan sesuai dengan gambar yang } \\
\text { ditampilkan melalui slide power point. }\end{array}$ & 75 \\
\hline
\end{tabular}




\begin{tabular}{|c|c|c|c|}
\hline No. & Kegiatan & Deskripsi & $\begin{array}{l}\text { Alokasi } \\
\text { Waktu }\end{array}$ \\
\hline & & $\begin{array}{l}\text { Menanya } \\
\text { Setelah mengamati dampak kegiatan manusia mahasiswa } \\
\text { termotivasi mempertanyakan dampak lingkungan secara } \\
\text { fisik, kimia, biologi, dan sosial. }\end{array}$ & \\
\hline & & $\begin{array}{l}\text { Eksperimen/Mengumpulkan Data } \\
\text { 1. Secara berkelompok, mahasiswa mengumpul-kan } \\
\text { data dengan mengerjakan LK untuk } \\
\text { mengidentifikasi dampak kegiatan manusia terhadap } \\
\text { lingkungan yang meliputi lingkungan fisik, kimia, } \\
\text { biologi, dan sosial. } \\
\text { 2. Mengidentifikasi dampak kegiatan manusia terhadap } \\
\text { lingkungan meliputi jenis kegiatan/ usaha atau } \\
\text { sumber polutan, jenis dampak/ polutan yang } \\
\text { ditimbulkan dan alternatif pemecahan masalah. }\end{array}$ & \\
\hline & & $\begin{array}{l}\text { Asosiasi/menalar } \\
\text { Menalar dengan menghubung-hubungkan dampak } \\
\text { kegiatan manusia terhadap lingkungan dari jenis } \\
\text { kegiatan/usaha atau sumber polutan, jenis dampak/ } \\
\text { polutan yang ditimbulkan dan menemukan beberapa solusi } \\
\text { sebagai alternatif pemecahan masalah yang dihadapi. }\end{array}$ & \\
\hline & & $\begin{array}{l}\text { Mengomunikasikan } \\
\text { 1. } \\
\text { Mahasiswa menyajikan hasil karya kerja kelompok } \\
\text { kelalui kunjung karya. Dua orang anggota dalam } \\
\text { kelompok bertugas sebagai penjaga stand hasil karya } \\
\text { kelompok lain, sementara 3-4 anggota kelompok } \\
\text { berkunjung ke kelompok lain dengan tugas } \\
\text { menanyakan dan memberi saran/masukan dari karya } \\
\text { kelompok yang dikunjungi. } \\
\text { 2. Selesai kunjung karya/karya kunjung setiap anggota } \\
\text { kelompok saling berbagi informasi dan } \\
\text { mendiskusikan masukan/saran dari kelompok lain } \\
\text { dan merevisi karya kelompok. Setelah itu karya } \\
\text { kelompok diplenokan. }\end{array}$ & \\
\hline 3 & Penutup & $\begin{array}{l}\text { 1. Merefleksi pembelajaran yang baru dilaksanakan dan } \\
\text { memberikan penguatan hal-hal yang belum terpahami } \\
\text { dengan baik. } \\
\text { 2. Mahasiswa merangkum materi yang dibelajarkan } \\
\text { 3. Memberikan evaluasi. } \\
\text { 4. Menginformasikan materi yang akan dibahas pada } \\
\text { pertemuan berikutnya. }\end{array}$ & 15 \\
\hline
\end{tabular}

Hasil observasi peneliti terhadap aktivitas belajar mahasiswa dalam mata kuliah pengetahuan lingkungan selama siklus pertama menunjukkan terdapat 13 mahasiswa sangat aktif dalam pembelajaran atau (31,71\%), 15 mahasiswa atau $(36,59 \%)$ dalam kategoti aktif dalam pembelajaran, dan terdapat 13 orang atau $(31,71)$ mahasiswa yang 
kurang aktif dalam proses pembelajaran. Hasil observasi aktivitas mahasiswa tersebut tergambar bahwa aktivitas belajar mahasiswa masih bervariasi. Terdapat 13 mahasiswa atau $(31,71 \%)$ yang belum aktif dalam kegiatan pembelajaran, dan terdapat $(68,29 \%)$ mahasiswa yang aktif dan sangat aktif mengikuti proses pembelajaran dan rerata keaktivan mahasiswa mengikuti proses pembelajaran sebesar $(72,36 \%)$. Oleh karena itu, keaktivan belajar secara klasikal belum tercapai sebagaimana yang diharapkan karena belum mencapai indikator yang ditetapkan yaitu sebesar $80 \%$.

Selain skor aktivitas belajar mahasiswa dalam mata kuliah pengetahuan lingkungan pada siklus pertama juga digambarkan hasil belajar yang diperoleh mahasiswa setelah dilakukan tes hasil belajar. Berdasarkan tes hasil belajar pada akhir siklus pertama diperoleh 4 orang mahasiswa $(9,76 \%)$ yang memperoleh skor kriteria amat baik, 18 orang mahasiswa $(43,90 \%)$ yang memperoleh skor dengan kriteria baik, 16 orang mahasiswa $(39,02 \%)$ memperoleh skor dengan kriteria cukup, dan 3 orang mahasiswa $(7,32 \%)$ memperoleh skor dengan kriteria cukup. Hasil tes belajar pada siklus pertama tersebut memberi gambaran bahwa hasil belajar mahasiswa masih bervariasi. Terdapat 22 mahasiswa atau $(53,66 \%)$ mahasiswa memperoleh skor amat baik dan baik, sementara masih terdapat 19 orang mahasiswa $(46,34 \%)$ dengan kriteria cukup dan kurang. Oleh karena itu disimpulkan bahwa hasil belajar belajar secara klasikal belum sesuai dengan yang diharapkan karena belum mencapai indikator keberhasilan perolehan hasil belajar di atas rerata skor 80 .

Berdasarkan skor perolehan aktivitas dan hasil belajar mahasiswa pada siklus yang pertama belum mencapai indikator yang ditetapkan, maka akan dilanjutkan pada siklus selanjutnya hingga aktivitas dan hasil belajar dicapai sesuai dengan indikator kinerja.

Pada tahap refleksi dan evaluasi hasil penelitian, peneliti bersama dengan observer yang ikut mengamati pelaksanaan tindakan siklus I berdiskusi untuk melakukan refleksi terhadap penerapan tindakan pembelajaran pada siklus I. Hasil diskusi peneliti dengan observer tentang refleksi-evaluasi pelaksanaan tindakan siklus I dirangkum sebagai berikut:

Pertama, dampak proses dari penggunaan pendekatan scientific yang dianggap berhasil diciptakan dalam pelaksanaan tindakan siklus I ini belum memenuhi harapan, tetapi lebih baik dari dampak proses pembelajaran sebelumnya. Beberapa hasil pengamatan serta catatan observer dan peneliti yang dianggap berhasil yaitu: (1) aktivitas dalam kegiatan pembelajaran sudah menunjukkan gejala menuju pembelajaran aktif dan kreatif; (2) keberanian mahasiswa dalam mengungkapkan ide dan gagasannya sudah mulai nampak yang ditunjukkan dengan kemauan mereka berpartisipasi aktif pada saat diskusi kelompok dan kunjung karya atau karya kunjung, walaupun masih perlu ditingkatkan; (3) interaksi antar mahasiswa dan dosen dalam pembelajaran yang dulunya jarang terjadi, sekarang mulai nampak; (4) interaksi antar mahasiswa dengan tutor sebaya dalam pembelajaran yang dulunya jarang terjadi, sekarang mulai nampak; 
(5) prestasi belajar terjadi peningkatan namun belum sesuai harapan; (6) aktivitas belajar mahasiswa dalam kegiatan pembelajaran sudah berjalan dengan baik, namun masih perlu perbaikan terutama pada aspek menyimpulkan materi pembelajaran.

Kedua, yang belum berhasil yakni: (1) peningkatan skor masing-masing aspek pada aktivitas belajar masih kecil, perlu ditingkatkan agar mencapai nilai rerata $80 \mathrm{ke}$ atas; (2) peningkatan nilai hasil belajar mahasiswa belum sesuai indikator keberhasilan, maka masih perlu ditingkatkan jumlah mahasiswa yang mencapai skor perolehan di atas rerata 80 .

Ketiga, diskusi peneliti dengan observer menyimpulkan beberapa hal yang menyebabkan belum berhasilnya kegiatan pembelajaran pada siklus I antara lain: (1) Penerapan pendekatan scientific belum optimal sepenuhnya, lebih khususnya interaksi mahasiswa dengan mahasiswa saat berdiskusi dalam kelompok kecil. Masih terdapat mahasiswa yang tidak berpartisipasi secara penuh dan ada pula mahasiswa yang mendominasi diskusi; (2) Selama ini pemberian tes hasil belajar sebagai penilaian akhir dilaksanakan pada akhir siklus atau pertemuan ketiga.

Keempat, untuk mencapai aktivitas dan hasil belajar yang lebih baik, maka perlu dilaksanakan kegiatan pembelajaran siklus II. Pada pelaksanaan kegiatan pembelajaran siklus II, perencanaan tindakan harus lebih disempurnakan dengan meningkatkan halhal yang dinilai berhasil namun belum optimal pada siklus I dan menambahkan beberapa strategi mengaktifkan mahasiswa dalam pembelajaran terhadap hal-hal yang yang dinilai belum berhasil dicapai. Beberapa hal yang menjadi rekomendasi untuk ditingkatkan dan disempurnakan pada siklus II sebagai perbaikan dari tindakan siklus I antara lain: (1) Menggunakan metode pembelajaran yang lebih bervariasi untuk mengaktifkan mahasiswa dalam proses pembelajaran; (2) Membuat rencana pelaksanaan pembelajaran untuk pertemuan pada siklus II berikutnya; (3) Memotivasi mahasiswa untuk lebih belajar.

\section{Siklus 2}

Pada tahap perencanaan siklus kedua, peneliti tetap menetapkan tiga kali pertemuan tatap muka. Topik-topik yang dibahas pada setiap pertemuan tersebut sebagai berikut: (1) sumber daya alam dan lingkungan hidup serta pengelolaannya, (2) kesehatan dan lingkungan dan, (3) polusi air dan tanah. Langkah-langkah pembelajaran pada siklus II dilakukan revisi berdasarkan refleksi pada siklus I. Namun, secara umum langkah perencanaan siklus II tetap mengikuti langkah pada siklus I sebagai berikut:

a. Membuat skenario pembelajaran sesuai dengan topik-topik materi pembelajaran untuk mencapai kompetensi dasar yang telah ditentukan dalam mata kuliah pengetahuan lingkungan.

b. Membuat instrumen yang digunakan untuk menilai aktivitas berupa lembar pengamatan dan hasil belajar berupa tes pengetahuan.

c. Menyiapkan alat dan bahan yang dibutuhkan dalam pembelajaran dengan pendekatan scientific seperti gunting, lem kertas, kertas plano, HVS dan post-it 
yang digunakan pada saat kunjung karya atau karya kunjung.

d. Menyiapkan gambar sesuai dengan konten materi untuk memudahkan mahasiswa mengamati permasalahan lingkungan hidup.

e. Membuat lembar kerja (LK) setiap pertemuan yaitu; (1) sumber daya alam dan lingkungan hidup serta pengelolaannya, (2) kesehatan dan lingkungan dan, (3) polusi air dan tanah.

f. Menyiapkan gambar/video sesuai dengan konten materi untuk memudahkan mahasiswa mengamati permasalahan lingkungan hidup.

g. Mengelompokkan mahasiswa menjadi kelompok-kelompok kecil yang beranggotakan antara 5-7 orang mahasiswa untuk mendiskusikan subtopik materi yang menjadi tugas kelompok.

h. Setelah presentasi hasil karya dalam bentuk pleno dilanjutkan evaluasi dengan model tongkat berbicara. Setiap mahasiswa diberi tugas untuk menuliskan pertanyaan pada sepotong kertas yang berkaitan dengan materi yang dibelajarkan. Setelah itu, diputar musik dan saat musik berhenti, dimana tongkat berada maka mahasiswa tersebut mencabut pertanyaan yang sudah disiapkan sebelumnya lalu dijawab.

Pada tahap pelaksanaan tindakan ini merupakan pelaksanaan dari RPP yang sudah didesain mengikuti pendekatan scientific. Contoh pelaksanaan pembelajaran di kelas dapat dilihat pada Tabel .

Tabel 4. Pelaksanaan RPP Siklus 2

\begin{tabular}{|c|c|c|c|}
\hline No. & Kegiatan & Deskripsi & $\begin{array}{l}\text { Alokasi } \\
\text { Waktu }\end{array}$ \\
\hline \multirow[t]{2}{*}{1} & Pendahuluan & $\begin{array}{l}\text { 1. Memberi salam, selanjutnya menanyakan kabar } \\
\text { mahasiswa. } \\
\text { 2. Memotivasi, apersepsi, dan menghubungkan } \\
\text { pengetahuan sebelumnya dengan materi yang akan } \\
\text { dibelajarkan. } \\
\text { 3. Menyampaikan tujuan pembelajaran dalam rangka } \\
\text { mencapai indikator kompetensi. } \\
\text { 4. Membimbing mahasiswa dalam pembentukan } \\
\text { kelompok. }\end{array}$ & 10 \\
\hline & Inti & $\begin{array}{l}\text { Mengamati } \\
\text { - Mengamati secara singkat penjelasan materi } \\
\text { melalui slide power point. } \\
\text { - Mengamati ciri-ciri sumber daya alam menurut } \\
\text { sifat, potensi, dan jenisnya yang ditampilkan } \\
\text { melalui slide power point. }\end{array}$ & 75 \\
\hline
\end{tabular}

\section{Menanya}

Setelah mengamati ciri-ciri sumber daya alam mahasiswa termotivasi mempertanyakan sifat, potensi, dan jenisn sumber daya alam dan lingkungan.

\section{Eksperimen/Mengumpulkan Data}

1. Secara berkelompok, mahasiswa mengumpulkan data 


\begin{tabular}{|c|c|c|c|}
\hline No. & Kegiatan & Deskripsi & $\begin{array}{l}\text { Alokasi } \\
\text { Waktu }\end{array}$ \\
\hline & & $\begin{array}{l}\text { dengan mengerjakan LK untuk menentukan pengaruh } \\
\text { sumber daya alam terhadap ling-kungan dihubungkan } \\
\text { dengan eksploitasi sumber daya alam menurut sifat, } \\
\text { potensi, dan jenisnya. } \\
\text { 2. Mengidentifikasi sumber daya alam menurut sifat } \\
\text { (renewable/deskripsi fungsinya, non- } \\
\text { renewable/deskripsi fungsinya, tidak habis/ deskripsi } \\
\text { fungsinya), potensi (materi/deskripsi fungsinya, } \\
\text { energi/deskripsi fungsinya, dan ruang/deskripsi } \\
\text { fungsinya), dan sifat (biotik/ deskripsi fungsinya, } \\
\text { abiotik/deskripsi fungsinya) } \\
\text { Asosiasi/menalar } \\
\text { Menalar dengan menghubung-hubungkan sumber daya } \\
\text { alam dan lingkungan hidup menurut sifat } \\
\text { (renewable/deskripsi fungsinya, non-renewable/ deskripsi } \\
\text { fungsinya, tidak habis/deskripsi fungsinya), potensi } \\
\text { (materi/ deskripsi fungsinya, energi/deskripsi fungsinya, } \\
\text { dan ruang/deskripsi fungsinya), dan sifat (biotik/ deskripsi } \\
\text { fungsinya, abiotik/deskripsi fungsinya) dan menemukan } \\
\text { beberapa solusi sebagai alternatif pemecahan masalah } \\
\text { melestarikan lingkungan. }\end{array}$ & \\
\hline & & $\begin{array}{l}\text { Mengomunikasikan } \\
\text { 1. Mahasiswa menyajikan hasil karya kerja kelompok } \\
\text { melalui kunjung karya. Dua orang anggota dalam } \\
\text { kelompok bertugas sebagai penjaga stand hasil karya } \\
\text { kelompok untuk menerima kunjungan dari kelompok } \\
\text { lain, sementara 3-4 anggota kelompok berkunjung ke } \\
\text { kelompok lain dengan tugas menanyakan dan } \\
\text { memberi saran/masukan dari karya kelompok yang } \\
\text { dikunjungi. } \\
\text { 2. Selesai kunjung karya/karya kunjung setiap anggota } \\
\text { kelompok saling berbagi informasi dan mendiskusikan } \\
\text { masukan/saran dari kelompok lain dan merevisi karya } \\
\text { kelompok. Setelah itu karya kelompok diplenokan. }\end{array}$ & \\
\hline 3 & Penutup & $\begin{array}{l}\text { 1. Merefleksi pembelajaran yang baru dilaksanakan dan } \\
\text { memberikan penguatan hal-hal yang belum terpahami } \\
\text { dengan baik. } \\
\text { 2. Merangkum materi yang dibelajarkan dilanjutkan } \\
\text { evaluasi dengan model tongkat berbicara. } \\
\text { 3. Menginformasikan materi yang akan dibahas pada } \\
\text { pertemuan berikutnya. }\end{array}$ & 15 \\
\hline
\end{tabular}

Hasil observasi aktivitas belajar mahasiswa dalam mata kuliah pengetahuan lingkungan selama siklus II menggambarkan terdapat 23 mahasiswa sangat aktif dalam pembelajaran atau $(56,10 \%), 13$ mahasiswa atau $(31,71 \%)$ dalam kategoti aktif dalam pembelajaran, dan 6 orang mahasiswa atau $(12,20 \%)$ yang kurang aktif dalam proses pembelajaran. Hasil observasi aktivitas mahasiswa pada siklus II tersebut menggambarkan bahwa aktivitas belajar mahasiswa masih bervariasi. Namun secara 
umum mahasiswa sudah dalam kategori sangat aktif dan aktif dalam proses pembelajaran yaitu sebesar $(87,80 \%)$. Sementara masih terdapat 6 orang mahasiswa yang kurang aktif atau (12,20\%). Oleh karena itu, keaktivan belajar secara klasikal sudah tampak sebagaimana yang diharapkan sudah mencapai indikator yang ditetapkan yaitu lebih sebesar $80 \%$.

Selain skor aktivitas belajar mahasiswa dalam mata kuliah pengetahuan lingkungan pada siklus II juga digambarkan hasil belajar yang diperoleh mahasiswa setelah dilakukan tes hasil belajar. Berdasarkan tes hasil belajar pada akhir siklus pertama diperoleh 11 orang mahasiswa $(26,83 \%)$ yang memperoleh skor kriteria amat baik, 25 orang mahasiswa $(60,98 \%)$ yang memperoleh skor dengan kriteria baik, dan 5 orang mahasiswa $(12,20 \%)$ memperoleh skor dengan kriteria cukup, dan tidak terdapat mahasiswa yang memperoleh skor kurang. Hasil tes belajar pada siklus II tersebut memberi gambaran bahwa hasil belajar mahasiswa masih bervariasi. Namun, pada umumnya mahasiwa sudah memperoleh skor amat baik dan baik dengan jumlah 36 orang atau $(87,80 \%)$. Oleh karena itu disimpulkan bahwa hasil belajar belajar secara klasikal sudah sesuai dengan yang diharapkan karena susah mencapai indikator keberhasilan perolehan hasil belajar di atas rerata skor 80. Berdasarkan skor perolehan aktivitas dan hasil belajar mahasiswa pada siklus yang II sudah mencapai indikator kinerja yang ditetapkan, maka penelitian tindakan ini berakhir pada siklus ke II.

Refleksi dan evaluasi pada pelaksanaan tindakan siklus II dilakukan peneliti bersama observer terhadap penerapan pendekatan scientific yang dilaksanakan pada siklus II. Hasil diskusi peneliti dengan observer tentang refleksi evaluasi pelaksanaan tindakan siklus II dirangkum sebagai berikut:

Pertama, penerapan pendekatan scientific dalam proses pembelajaran dianggap berhasil dalam pelaksanaan tindakan siklus II ini karena sudah memenuhi harapan sesuai indikator kinerja yang ditetapkan yaitu skor aktivitas dan hasil belajar di atas rerata 80. Beberapa hasil pengamatan serta catatan observer dan peneliti diuraikan sebagai berikut: (1) Aktivitas dalam kegiatan pembelajaran sudah menunjukkan pembelajaran aktif dan kreatif; (2) Keberanian mahasiswa dalam mengungkapkan ide dan gagasannya sudah nampak, ditunjukkan dengan kemauan mereka berpartisipasi aktif pada saat diskusi kelompok dan kunjung karya atau karya kunjung, sehingga perlu dipertahankan; (3) Interaksi antar mahasiswa dan dosen dalam pembelajaran berjalan dengan baik dan sistem sosial dalam proses pembelajaran terjadi multi arah; (4) Prestasi belajar terjadi peningkatan namun dan indikator kinerja yang ditetapkan telah tercapai.

Kedua, yang belum berhasil, yakni: (1) Peningkatan skor masing-masing aspek pada aktivitas belajar masih kecil, perlu ditingkatkan agar mencapai nilai rerata $80 \mathrm{ke}$ atas; (2) Peningkatan nilai hasil belajar mahasiswa sudah sesuai indikator keberhasilan, namun masih terdapat 5 orang mahasiswa yang memperoleh nilai kurang dari skor perolehan di atas rerata 80.

Ketiga, berdasarkan refleksi dan evaluasi peneliti pada siklus II aktivitas dan hasil 
belajar mengalami penlingkatan sebagaimana yang diharapkan. Hal tersebut sesuai dengan indikator kinerja telah ditentukan sehingga penelitian tindakan ini berakhir sampai siklus II.

\section{Pembahasan}

Keaktifan mahasiswa dalam proses pembelajaran pada refleksi awal sebesar $60,00 \%$, pada siklus pertama mengalami peningkatan menjadi 72,36\%, dan siklus ketiga menjadi $84,76 \%$. Prosentase ini menunjukkan bahwa selama proses pembelajaran terjadi peningkatan partisipasi belajar pada mata kuliah pengetahuan lingkungan mahasiswa semester II, Prodi Pendidikan Biologi Fakultas Tarbiyah dan Keguruan Tahun Akademik 2013/2014.

Pada siklus pertama keaktifan mahasiswa pada pembelajaran dengan pendekatan scientific belum mencapai hasil seperti yang diharapkan. Sebahagian mahasiswa belum berani mengungkapkan ide dan gagasannya meskipun sudah terjadi peningkatan saat diskusi kelompok dan kunjung karya, namun masih perlu perbaikan terutama pada aspek partisipasi dalam menyimpulkan materi pembelajaran. Mahasiswa yang belum aktif dalam proses pembelajaran karena masih takut bertanya ataupun menjawab karena takut apabila jawaban salah atau pertanyaannya kurang dihargai. Dengan demikian pendidik harus lebih banyak memberi motivasi dan dorongan kepada mahasiswa bangkit semangatnya, sehingga mau aktif dan terlepas dari takut salah.

Selain itu, setelah presentasi hasil karya dalam bentuk pleno dilanjutkan evaluasi dengan model tongkat berbicara. Setiap mahasiswa diberi tugas untuk menuliskan pertanyaan pada sepotong kertas yang berkaitan dengan materi yang baru dipelajari. Setelah itu, tongkat dimainkan diiringi musik dan saat musik berhenti dimana tongkat berada maka mahasiswa tersebut akan mencabut pertanyaan kemudian dibaca dan jawab.

Pada pelaksanaan proses belajar mengajar siklus kedua keaktifan mahasiswa tampak meningkat dan merasa senang mengikuti pembelajaran. Pada saat pembelajaran dengan pendekatan scientific, mahasiswa dapat melakukannya dengan baik. Keberanian mahasiswa dalam mengungkapkan ide dan gagasannya sudah nampak, ditunjukkan dengan kemauan mereka berpartisipasi aktif pada saat diskusi kelompok dan kunjung karya atau karya kunjung sehingga perlu dipertahankan. Demikian pula interaksi antar mahasiswa dan dosen dalam pembelajaran berjalan dengan baik dan sistem sosial dalam proses pembelajaran terjadi multi arah.

Peningkatan aktivitas belajar pada mata kuliah pengetahuan lingkungan juga diikuti peningkatan hasil belajar yang diperoleh mahasiswa. Pada akhir siklus pertama 4 orang mahasiswa $(9,76 \%)$ yang memperoleh skor kriteria amat baik, 18 orang mahasiswa $(43,90 \%)$ yang memperoleh skor dengan kriteria baik, 16 orang mahasiswa $(39,02 \%)$ memperoleh skor dengan kriteria cukup, dan 3 orang mahasiswa $(7,32 \%)$ memperoleh skor dengan kriteria cukup. Rerata perolehan hasil belajar pada siklus pertama adalah 77,56. Sedangkan pada siklus kedua terdapat 11 orang mahasiswa 
$(26,83 \%)$ yang memperoleh skor kriteria amat baik, 25 orang mahasiswa $(60,98 \%)$ yang memperoleh skor dengan kriteria baik, dan 5 orang mahasiswa $(12,20 \%)$ memperoleh skor dengan kriteria cukup, dan tidak terdapat mahasiswa yang memperoleh skor kurang. Rerata skor perolehan hasil belajar pada siklus kedua adalah 83,78. Dengan demikian terjadi peningkatan skor hasil belajar dari siklus pertama ke siklus kedua sebesar 6,22.

Berdasarkan temuan penelitian ini maka peneliti menyimpulkan bahwa pendekatan scientific dalam pembelajaran dapat meningkatkan keaktifan dan hasil belajar mahasiswa. Meskipun demikian, masih terdapat kelemahan dalam penelitian ini terutama dalam aspek aktivitas belajar karena hanya dibatasi pada indikator interaksi mahasiswa dengan dosen, interaksi antar mahasiswa, kerjasama kelompok dan partisipasi mahasiswa dalam menyimpulkan materi pembelajaran. Sementara indikator pada aspek aktivitas belajar masih banyak selain yang dibahas dalam penelitian ini.

\section{SIMPULAN}

Simpulan dari penelitian ini yakni penerapan pendekatan scientific dalam pembelajaran mata kuliah pengetahuan lingkungan hidup dapat meningkatkan aktivitas belajar mahasiswa. Skor perolehan aktivitas belajar mahasiswa pada aspek yang diamati dalam pembelajaran siklus I dengan persentase rerata $72,36 \%$ dan pada siklus II meningkat menjadi rerata $84,76 \%$. Hal ini berarti terjadi peningkatan sebesar $12,40 \%$. Begitu pula dengan hasil belajar mahasiswa dengan penerapan pendekatan scientific cenderung semakin meningkat dari siklus I ke siklus II. Hal ini dapat di lihat dari skor rerata yang diperoleh mahasiswa meningkat yaitu rerata 77,56 pada siklus I menjadi rerata 83,78 pada siklus II. Dengan demikian terjadi peningkatan skor hasil belajar dari siklus pertama ke siklus kedua sebesar 6,22.

\section{DAFTAR PUSTAKA}

Atsnan, M.F., dan Rahmita, Yuliana Gazali. (2013). Penerapan Pendekatan Scientific dalam Pembelajaran Matematika SMP Kelas VII Materi Bilangan (Pecahan). Prosiding Seminar Nasional Matematika dan Pendidikan Matematika. ISSN 978 - 979 - 16353 - 9 - 4. Online. (Diakses di http://eprints.uny.ac.id/id/eprint/10777, pada 1 Oktober 2014)

Dewey, J. (1938). Experience and education (1st ed.). New York: Touchstone.

Djamarah, Syaiful Bahri. (2008). Psikologi Belajar. Jakarta : Rineka Cipta.

Nurohman, Sabar. (2008). "Pendekatan Project Based Learning sebagai Upaya Internalisasi Scientific Method bagi Mahasiswa Calon Guru Fisika." Jurnal FPMIPA UNY: Tidak diterbitkan. Online, (Diakses di http:// ejournal.undiksha.ac.id/index.php/ semnasmipa/ article/view/2688 /2270, pada 22 
Maret 2014).

Kementerian Pendidikan dan Kebudayaan. Peraturan Menteri Pendidikan Nasional Nomor 81A Tahun 2013 tentang Implementasi Kurikulum 2013.

Piaget, J. (1950). Psychology of intelligence. New York: Routledge.

Republik Indonesia, (2009). Undang-Undang No. 20 Tahun 2003 Tentang Sistem Pendidikan Nasional. Cet. II; Jakarta: Sinar Grafika.

Romanov, Kalle \& Nevgi, Anne. (2008). Student activity and learning outcomes in a virtual learning environment. Learning Environ Res (2008) 11:153-162

Rusman N dan Abd. Rahman, (2010). Panduan Pengembangan Profesi Guru dan PTK, Depok: Karisma.

Sanjaya, Wina. (2011). Strategi Pembelajaran Berorintasi Standar Proses Pendidikan, Jakarta: Kencana Prenada Media.

Suparman, Atwi. (2012). Desain Instruksional Modern: Panduan Para Pengajar dan Inovator Pendidikan, Jakarta: Erlangga.

Taniredja, Tukiran. (2010). Penelitian Tindakan Kelas untuk Pengembangan Profesi Guru. Bandung: Alfabeta.

Tim Penulis. (2013). Pedoman Edukasi UIN Alauddin Makassar. Makassar: UIN Alauddin

Vygotsky, L. S. (1978). Mind and society: The development of higher mental processes. Cambridge, MA: Harvard University Press.

Yaumi, Muhammad dan Ibrahim. (2013). Pembelajaran Berbasis Kecerdasan Jamak, Jakarta: Kencana Prenadamedia Group.

Yatmoko, Susilo Fitri. Aktivitas-aktivitas Belajar Siswa. Online: (Diakses di http://susilofy. wordpress.com/2011/01/18/aktivitas-aktivitas-belajar-siswa/, pada 22 Maret 2014). 